Discussion Paper No. 10-017

Don't Tax Me?

Determinants of Individual Attitudes

Toward Progressive Taxation

Friedrich Heinemann and Tanja Hennighausen

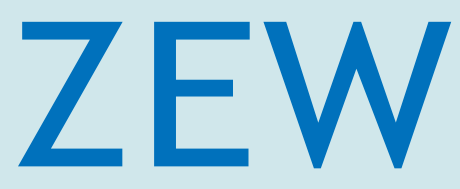

Zentrum für Europäische Wirtschaftsforschung $\mathrm{GmbH}$

Centre for European

Economic Research 


\section{Discussion Paper No. 10-017 \\ Don't Tax Me? \\ Determinants of Individual Attitudes Toward Progressive Taxation}

Friedrich Heinemann and Tanja Hennighausen

Download this ZEW Discussion Paper from our ftp server:

ftp://ftp.zew.de/pub/zew-docs/dp/dp10017.pdf

Die Discussion Papers dienen einer möglichst schnellen Verbreitung von neueren Forschungsarbeiten des ZEW. Die Beiträge liegen in alleiniger Verantwortung der Autoren und stellen nicht notwendigerweise die Meinung des ZEW dar.

Discussion Papers are intended to make results of ZEW research promptly available to other economists in order to encourage discussion and suggestions for revisions. The authors are solely responsible for the contents which do not necessarily represent the opinion of the ZEW. 


\section{Non-Technical Summary}

Highly progressive tax systems entail disincentives for private economic activity and, thus, may hamper potential growth. Nevertheless, attempts to introduce alternative tax schedules regularly encounter significant political resistance. The aim of this paper is to widen the understanding of the determinants of individual attitudes toward progressive taxation and, therefore, the assessment of the political feasibility of tax reform proposals.

Conventional political-economic theories usually explain redistributive preferences based on a narrow self-interest calculus. These theories however do not offer a rational for the fact that in many industrial countries the majority of voters seem to prefer progressive tax rates. In order to provide a comprehensive analysis of the determinants of individual attitudes toward progressive taxation, our analysis is not confined to pure self-interest but also introduces fairness aspects (e.g., fairness preferences, economic beliefs and fairness assessment of the status quo).

Our empirical analysis is based on the representative data from the German General Social Survey (ALLBUS) for the year 2000. Next to information on the respondents' tax rate preferences, this survey offers valuable data on a wide range of individual fairness considerations as well as objective data on the respondents' socioeconomic characteristics.

The empirical findings indicate that the individual attitudes toward progressive taxation are not only driven by the corresponding self-interest. Furthermore, fairness considerations play a major role in the formation of tax rate preferences: Persons without strong preferences for a distribution of (financial) means according to the need-principle, who do stress the relevance of individual effort for economic success and judge the present income distribution to be fair are less likely to demand higher tax rates for high income earners than for low income individuals. The finding that individuals do not necessarily choose the tax system that is most beneficial to them but also care about its fairness has important policy implications: A successful selling of (growth-enhancing) tax reforms should address this fairness related concerns as well. 


\section{Zusammenfassung}

Eine progressive Einkommensbesteuerung kann sich zwar negativ auf die individuellen Anreize für privatwirtschaftliche Aktivität und damit auch auf das gesamtwirtschaftliche Wachstum auswirken, Reformvorhaben mit dem Ziel der Einführung alternativer Steuersysteme stoßen jedoch regelmäßig auf erheblichen politischen Widerstand. Die vorliegende Arbeit soll daher zu einem besseren Verständnis der Determinanten der individuellen Einstellung gegenüber progressiver Besteuerung und damit auch der politischen Durchsetzbarkeit entsprechender Reformmaßnahmen beitragen.

Traditionelle polit-ökonomische Ansätze unterstellen, dass persönlicher Eigennutz maßgeblich für die Zustimmung zu Umverteilungsmaßnahmen ist. Allerdings können vornehmlich eigennutzbasierte Modelle keine Begründung dafür liefern, dass in vielen Industrieländern scheinbar eine Mehrheit der Wähler progressive Steuersysteme bevorzugt. Um eine möglichst umfassende Analyse der Determinanten der individuellen Präferenzen für Steuerprogression zu erhalten, werden neben vornehmlich eigennutzbasierten Erklärungsfaktoren auch Fairnessaspekte (z.B. Gerechtigkeitspräferenzen, wirtschaftliche Beliefs und die wahrgenommene Gerechtigkeit des Status quo) betrachtet.

Die empirischen Analysen basieren auf repräsentativen Umfragedaten für Deutschland, die im Rahmen der Allgemeinen Bevölkerungsumfrage der Sozialwissenschaften (ALLBUS) im Jahr 2000 erhoben wurden. Neben Informationen über Steuerpräferenzen enthält ALLBUS zahlreiche Daten zu individuellen Gerechtigkeitsüberlegungen sowie der objektiven sozioökonomischen Situation der Befragten.

Die Ergebnisse unserer empirischen Untersuchung zeigen, dass die individuelle Einstellung gegenüber einer progressiven Besteuerung nicht alleine durch Eigennutzüberlegungen determiniert wird. Vielmehr spielen Gerechtigkeitsüberlegungen bei der Präferenzenbildung eine maßgebliche Rolle: Personen, die keine ausgeprägte Präferenz für eine Verteilung auf Basis des Bedarfsprinzips aufweisen, die individuelle Anstrengung als wesentlich für wirtschaftlichen Erfolg erachten und die bestehende Einkommensverteilung als gerecht beurteilen, fordern weniger häufig progressive Steuersätze. Mit der Erkenntnis, dass Individuen nicht immer dasjenige Steuersystem präferieren, das ihnen selbst den größten Nutzen verspricht, sondern auch Fairnessmotive in ihrem Urteil berücksichtigen, gehen wichtige politische Implikationen einher: So sollte eine erfolgreiche Präsentation von (wachstumsfördernden) Steuerreformen auch auf Gerechtigkeitsaspekte eingehen. 


\title{
Don't Tax Me? \\ Determinants of Individual Attitudes Toward Progressive Taxation
}

\author{
Friedrich Heinemann ${ }^{\dagger}$ and Tanja Hennighausen ${ }^{\ddagger}$ \\ $\dagger$ ZEW Mannheim \\ $\ddagger$ ZEW Mannheim and University of Mannheim
}

March 2010

\begin{abstract}
This contribution empirically analyses the individual determinants of tax rate preferences. For that purpose we make use of the representative German General Social Survey (ALLBUS) that offers data on the individual attitudes toward progressive, proportional, and regressive taxation. Our theoretical considerations suggest that beyond self-interest, information, fairness considerations, economic beliefs and several other individual factors drive individual preferences for tax rate structures. Our empirical results indicate that the self-interest view does not offer the sole explanation for the heterogeneity in attitudes toward progressive taxation. Rather, we show that the choice of the favoured tax rate is also driven by fairness considerations.
\end{abstract}

Key Words: tax progression, policy preferences, fairness, ALLBUS

JEL Classification: H89, D63, C42, A13

Acknowledgements: We would like to thank Fritz Böhringer for helpful comments and suggestions and the "Böhringer Ilsfeld Stiftung" for financial support.

\footnotetext{
${ }^{\dagger}$ Centre for European Economic Research (ZEW)

Phone: + +49621 1235149

$\mathrm{L} 7,1$

Fax: $\quad+496211235223$

D-68161 Mannheim, Germany

E-mail: heinemann@zew.de

${ }_{\ddagger}^{\ddagger}$ hennighausen@zew.de
} 


\section{Introduction}

Highly progressive tax systems confront high income individuals and companies with substantial marginal tax rates. Thus, they entail disincentives for private economic activity and may hamper potential growth. Therefore, the introduction of alternative tax systems might be a desirable part of a growth enhancing fiscal strategy. However, a transition towards a less progressive tax schedule or even a flat tax is regularly confronted with opposition. Radical flat tax regimes have only been possible within very few countries. Obviously, tax progression is a majority preference in many industrial countries.

The reasons for the popularity of tax progression are not well understood. Basically, two alternative but not necessarily mutual exclusive explanations compete: self-interest and fairness concerns.

The self-interest view is firmly rooted in political-economic theories of public redistribution. These approaches postulate that individuals choose their preferred tax rate based on a narrow self-interest calculus (e.g., Hettich and Winer, 1997). Thus, increasing income redistribution should be supported by persons that benefit financially (net recipients) and opposed by those who are net payers to the welfare state (e.g., Meltzer and Richard, 1981). From that perspective, tax progression is popular simply because its distributive costs are imposed on a minority of voters.

The fairness view is supported by a more recent literature which indicates that the concept of the purely rational homo oeconomicus may be misleading since it has been shown empirically that fairness motives are likely to affect individual decision making (e.g., Konow, 2003) and policy preferences (e.g., Heinemann et al., 2009). From that perspective, people support progression because they regard it as fairer compared to a flat tax schedule.

This paper wants to widen the understanding for the relative merits of both explanations. The basic analytical idea originates from the fact that both explanations should differ in their empirical outcomes with respect to one key property. If the self-interest view offers the sole relevant explanation, than the support or rejection of progression should be largely driven by proxies which indicate a winner/loser position vis-à-vis tax progression. If, however, fairness considerations are also relevant, even losers from tax progression may be among its supporters.

Thus, this contribution fills an important gap in our understanding of tax system preferences. Here it is of substantial policy relevance since the knowledge of the determinants of individual tax preferences is crucial when it comes to an assessment of the political feasibility of tax reform proposals.

This paper relates to empirical analyses of individual preferences for income redistribution (e.g., Corneo and Grüner, 2002; Alesina and Fuchs-Schündeln, 2007; Alesina and Giuliano, 
2009). However, we do not focus on general preferences for redistribution but on attitudes toward progressive taxation. The empirical evidence indicates that self-interest may not be the only impact factor of individual attitudes on tax progression. Although Hite and Roberts (1991) find that self-interest is partly reflected in taxpayers' assessment of vertical equity of income tax, Wilensky (1976) shows that the perceived fairness of taxes depends mainly on subjective feelings rather than on their objective level or equity. Nevertheless, his results suggest a self-serving bias in taxpayers' perception since they assess their own (income) group as relatively deprived, while the position of other taxpayers is considered as beneficial. Indicating the relevance of fairness aspects, Ackert et al. (2006) offer experimental evidence on decisions about tax structures stressing the high explanatory impact of inequality aversion (as suggested by the Fehr-Schmidt model (Fehr and Schmidt, 1999)). Furthermore, Slemrod (2006) shows that US-citizens are more likely to support a substantial tax reform if they judge the current system to be unfair.

Our results are based on data from the German General Social Survey (ALLBUS) which is designed to be representative for the German population. ALLBUS includes questions on the preferred structure of tax rates and several fairness aspects as well as information on socioeconomic characteristics of the respondents. The findings indicate that individual tax attitudes do not only reflect the respondents' financial benefits of a certain tax structure but are found to be driven by fairness considerations as well. Hence, we reject the view that the popularity of tax progression results simply from income distribution (as suggested by Meltzer and Richard, 1981) and the fact that the winners of progression have a majority of votes. Although we control for the respondents' social status, fairness related indicators contribute substantially to explaining individual variance in progression preferences.

The remainder of this paper is organised as follows: The second section offers some facts about the attitudes toward progressive taxation among German voters. The subsequent section is devoted to the identification of the individual determinants of preferences for progressive tax rates. The econometric results are presented in section 4 and some concluding remarks are offered in section 5 . 


\section{Attitudes toward progressive taxation within the German population}

To analyse the individual determinants of voters' attitudes toward progressive taxation, we employ data from the German General Social Survey (ALLBUS). ${ }^{4}$ This data set entails valuable information on the respondents' assessment of several policies and political reform fields. Furthermore, ALLBUS offers data on the participants' socioeconomic situation as well as their economic and fairness beliefs, fairness preferences and judgements on the fairness of the status quo. This survey has been conducted biannually since 1980 and is designed to be representative for the German population. ${ }^{5}$ In the present study, we focus on data collected in the year 2000 survey that includes also questions designed for the International Social Survey Programme (ISSP). In the context of the ISSP-survey Social Inequality III the respondents were asked to answer the following question related to their tax preferences: Do you think people with high incomes should pay a larger share of their income in taxes than those with low incomes, the same share or a smaller share? The participants could choose between the following answers: People with high incomes should pay a larger or much larger share, the same share or a smaller respectively a much smaller share of their incomes in taxes than people with lower incomes. While the first two alternatives relate to progressive tax rates, the latter correspond to a proportional respectively regressive income taxation.

Figure 1 depicts the response pattern. It is remarkable that a clear majority of the German population (nearly 80 percent) seems to be in favour of a progressive taxation. ${ }^{6}$ The share of the respondents' preferring a proportional tax rate is considerably lower (19 percent), while the number of individuals choosing a regressive taxation can be neglected. The three bars on the right show the tax structure preferences for different income groups. ${ }^{7}$ Following political-economic models, we would expect a strong link between a person's income and his

\footnotetext{
${ }^{4}$ Further information is made available on the ALLBUS website: http://www.gesis.org/en/services /data/survey-data/allbus/

${ }^{5}$ From 1980 to 1986 and in 1991, the ALLBUS program was funded by the DFG. For all other surveys, state and federal funding has made available trough GESIS (Gesellschaft sozialwissenschaftlicher Infrastruktureinrichtungen). ALLBUS/GGSS is a joint project of the Center for Survey Research and Methodology (ZUMA - Zentrum für Umfragen, Methoden und Analysen e.V., Mannheim) and the Central Archive for Empirical Social Research (ZA- Zentralarchiv für Empirische Sozialforschung, Cologne) in cooperation with the ALLBUS scientific council. Data and documentation are obtainable through the Central Archive for Empirical Social Research (ZA, Cologne). The institutions and persons mentioned above bear no responsibility for the use or interpretation of the data in this publication.

${ }^{6}$ It is possible that this result is rather upward biased since the respondents may be not familiar with the concept of tax progression. Several studies indicate that individuals tend to choose a higher degree of progression when confronted with abstract questions (like the one used here) rather than on examples offering concrete tax liabilities for different income groups (e.g., Roberts et al., 1994).

${ }^{7}$ The allocation of the ALLBUS participants is based on their self-assessed net monthly income. The net income of the $25^{t h}$ percentile is below 650 Euro, while the individuals belonging to the $75^{t h}$ percentile earn at least 1529 Euro.
} 
Figure 1: Preferences on income tax share for high income people

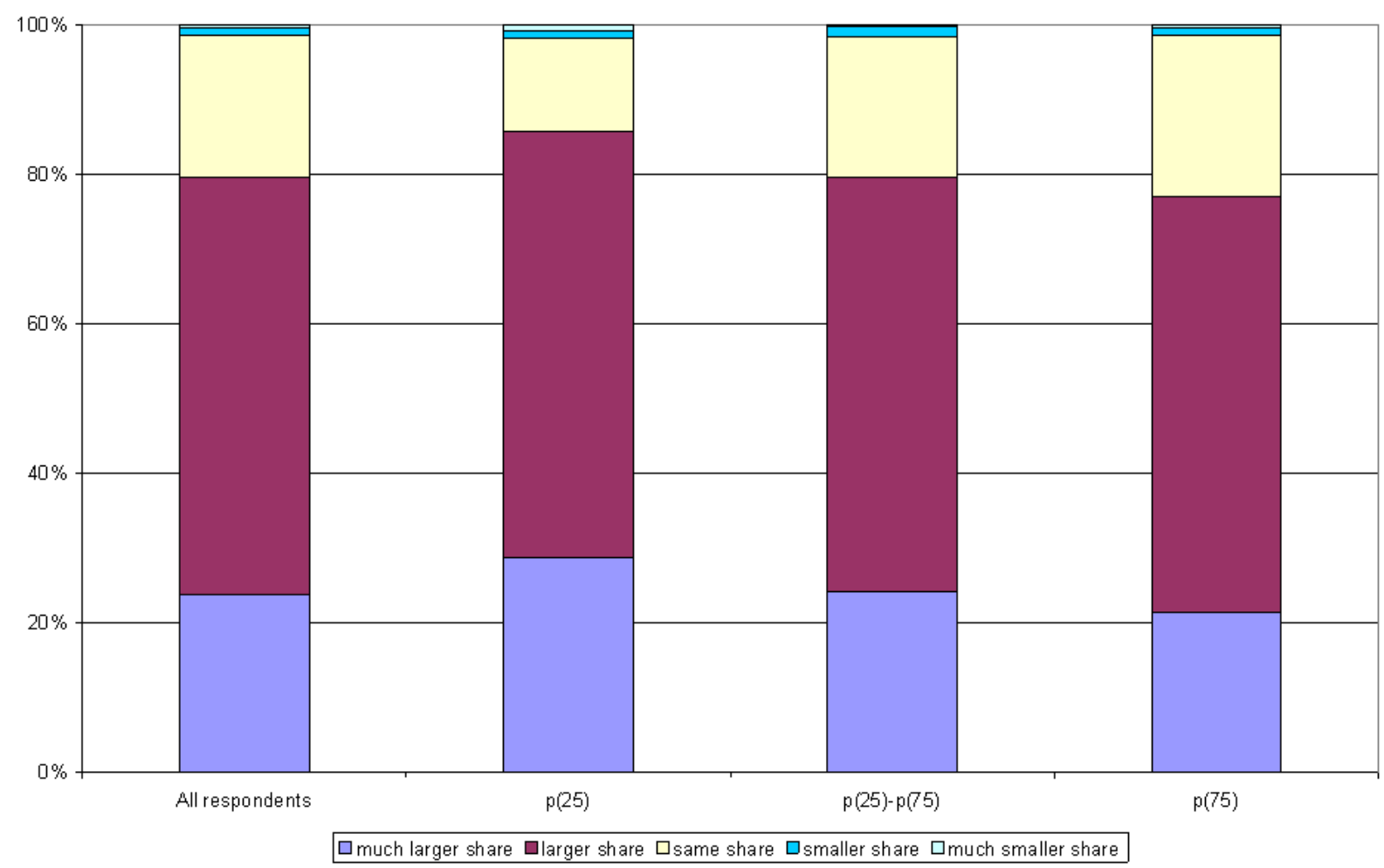

preferences concerning taxation (e.g., Hettich and Winer, 1997). In their application of a median voter framework Meltzer and Richard (1981) analyse the resulting level of income redistribution. The decisive median voter will choose a positive tax rate as long as he has a below average income and thus benefits from income redistribution.

Applied to the individual attitudes toward different tax rates, we expect people with high incomes to be less likely to choose a progressive tax rate than those with low incomes. However, Figure 1 reveals a surprising uniformity of opinion across the different income groups. Even though the share of respondents favouring a progressive taxation is in fact decreasing in income, the relationship seems to be rather weak. Although they bear financial losses from a progressive tax rate, still 77 percent of the participants belonging to the upper income quantile prefer such a tax scheme (compared to 86 percent of the respondents within the $25^{t h}$ percentile).

The majority of voters seem to approve a tax system that draws more on persons' with high income than on those with a lower income. Although self-interest seems to correspond to these attitudes, the link is far from being as close as suggested by conventional political- 
economic theory. ${ }^{8}$ This raises the question for other relevant driving factors (besides selfinterest) of individual attitudes toward tax structures. Since taxation is an instrument of the government to redistribute market incomes, it is reasonable to expect that fairness aspects play a major role in the formation of the corresponding attitudes.

\section{Potential determinants of individual attitudes towards progressive taxation}

The individual views on the design of the tax structure potentially depend on very different factors. First, self-interest should be important as individuals are affected differently by a given tax design. Second, the level of information about taxation might differ. Furthermore, people may entertain diverging beliefs on the role of incentives and the reasons of inequality. This can result in different conclusions about the effectiveness and necessity of progressive taxation. Third, it is reasonable to assume that individuals judge tax structures based on their views on the fairness of the existing income distribution. Thus, the following section is devoted to the identification of potential drivers of the diverging attitudes toward progressive taxation and their potential impact on tax policy assessment.

\section{Self-interest}

Political-economic models suggest that individual support for or resistance against income redistribution is driven mainly by self-interest. While the net-recipients of purely redistributive policies should be in favour of their expansion, net-payers should oppose these measures. Meltzer and Richard (1981) show that the median voter will choose a positive tax rate as long as he earns less than the population average and thus benefits financially from income redistribution. ${ }^{9}$ Applied to the decision about the degree of tax progression, one would expect support from individuals that are net-recipients from such a policy. Since the tax liability is disproportionately higher for wealthy individuals than for those with low incomes, it is reasonable to expect that former will be less likely to support a progressive tax scheme. ${ }^{10}$ Financial self-interest has been proved relevant for the assessment of tax policies (for a survey see McGowan, 2000). Hite and Roberts (1991) find that individuals in higher income brackets are less content with the fairness of steeply progressive tax rates. Furthermore, the financial situation of individuals has been found to affect the perceived fairness of different

\footnotetext{
${ }^{8}$ On the other hand, it is not clear whether the weak link between a persons income and his tax preferences reflects the possibility that person with an income above the $75^{t h}$ percentile do not regard themselves as high income recipients. If this is the case, the desire for progressive taxation may be motivated by self-interest: The people want others (the rich) to pay taxes.

${ }^{9}$ The voters take work disincentives due to redistribution and the resulting welfare loss into account.
} 
taxes or tax systems (e.g., Slemrod, 2006; Dornstein, 1987) as well as the support of actual reforms (e.g., Edlund, 1999).

Simple political-economic models are, however, not able to explain why individuals support redistributive policies (e.g., via a progressive taxation) although they have to bear financial losses from it. One possible explanation based on self-interest is offered by Bénabou and Ok (2001). Given the possibility of income mobility, it might be rational for the currently rich (poor) to support (oppose) redistribution if they expect to earn less (more) than the population average in the future. Another aspect of income mobility has been stressed by Piketty (1995). Experienced social mobility is likely to form the beliefs concerning the relative importance of individual effort for economic success. Individuals who experienced upward mobility may stress the relevance of effort, while those facing a loss in social status may ascribe this to bad luck (this has been proven empirically for Russia, see Ravallion and Lokshin, 2000). Using US survey data, Alesina and Giuliano (2009) find that upward mobility tends to decrease individual preferences for redistribution.

To account both for the respondents' static and dynamic (i.e. mobility related) self-interest we exploit information of self-reported social status over time. ${ }^{11}$ ALLBUS contains data about the respondents' placement in the social stratum in the year the survey has been conducted as well as 10 years ago. Based on this information we construct the variables social status $^{12}$ and social mobility. The latter takes a negative value for individuals experiencing downward mobility and a positive value for those who experienced upward mobility. For the corresponding regression coefficients negative signs are expected.

\section{Information}

The level of information has found to influence the individual assessment of economic policy. Boeri et al. (2002) and Boeri and Tabellini (2007) show that a better knowledge of the functioning and costs of unfunded pension systems relates to a higher support for pension reforms. Heinemann et al. (2009) find that highly educated and politically informed persons are more likely to approve labour market deregulations. In the context of tax systems, the level of information is likely to be reflected in individual policy assessments.

\footnotetext{
${ }^{11}$ ALLBUS offers only information on the respondents' reported net income. To assess the financial selfinterest related to tax structures, we would need information on their incomes before taxes and transfers. Furthermore, a considerable share of ALLBUS participants do not report their income. Using the individual net income as a proxy for self-interest is related to a substantial loss of observations. Table A2 (in the appendix) shows that the social status is positively correlated to both the reported net income and the level of education. We also conducted regression using the individuals' income instead of their social status and found that the results remain robust (obtainable from the authors).

${ }^{12}$ This variable is based on a ordinal scale from 1 to 10 . A high (low) value corresponds to a position at the top (bottom) of the society. More information on this and other included variables is available in Table A3 in the appendix.
} 
Slemrod (2006) argues that the observable preference of US citizens for a flat or sales tax mirrors at least partly misconceptions about the degree of tax progression of the current system. Furthermore, Sheffrin (1993) points out that tax policy concepts are rather complex and not discussed properly in the public. The general publics' lack of knowledge about taxation (especially related to the concept of progression) is reflected in the fact that the framing of survey questions is likely to affect the respondents' answers (Roberts et al., 1994). Confronted with abstract questions the majority of the respondents seems to prefer a progressive system, which is not the case if the respondents are offered a concrete example (e.g., declaration of just tax payments for different income groups). Furthermore, the evaluation of tax structures depends on whether the tax payments of different income groups have been presented in rates or in absolute values.

Thus, we would expect that the individual level of information about the tax system should be relevant for the corresponding answer behavior. Unfortunately, ALLBUS offers no direct information on the respondents' knowledge about taxation and different tax schemes. Nevertheless, an empirical analysis of individual attitudes toward progressive taxation should take the respondents' level of information into account (at least to minimize possibly biased results due to minor knowledge).

We make use of two variables to proxy the respondents' degree of information about taxation: First, we control for the level of education by introducing a dummy variable university equal to one for university (as well as university of applied science) graduates. In addition, we employ the respondents' opinion on the importance of politics for his personal life. The perception that political decisions affect the own life and well-being should increase the incentive to be informed about major political topics. This relationship has been stressed by Edlund (2003) who argues that the high relevance of fiscal policy for the Swedish population due to the welfare state generousity involves a stronger awareness of topics related to public finance. Although we would expect that a better information level reduces biases and misunderstandings, we do not have any a priori knowledge about the direction of this bias.

\section{Beliefs}

The relevance of beliefs (e.g., concerning the underlying reasons of inequality) for welfare state preference has been emphasized by Alesina and Angeletos (2005). It has been shown empirically that beliefs on the impact of individual effort relative to exogenous factors (like birth or luck) can explain differences in welfare state preferences (Alesina et al., 2001; Corneo and Grüner, 2002) as well as in fairness judgements (Faravelli, 2007; Bischoff et al., 2008). The implicit assumption that everyone is responsible for his own economic situation and that existing inequality results from differences in individual effort should lead to a less 
favourable assessment of progressive taxation. The same is expected for individuals believing that incentives affect individual effort. The disincentives of increasing marginal tax rates for private economic activity should be weighted more and, thus, lead to a more critical assessment of tax progressivity. The respondents' beliefs concerning the reasons for economic success are captured by the dummy variable effort. This variable takes on the value one for participants stating that differences in social status reflect individual variations in effort. For the corresponding regression coefficient a negative sign is expected.

A further belief that may be relevant for tax preferences is related to the procedural fairness of the political system. Following the concept of procedural fairness, the perceived justice of a certain (policy) outcome depends on the underlying decision making process. Procedurally fair decisions should meet criteria like a voice for everyone, neutral decision makers and transparent decision procedures (as stated by Leventhal, 1980 and Tyler, 2000). It has been shown that procedural fairness increases the acceptance of decisions with unfavourable outcomes (e.g., Sondak and Tyler, 2007) as well as the perceived fairness of social inequality (Bischoff et al., 2008). The respondents' beliefs on the degree of procedural fairness of the German political system is measured based on their assessment of the functioning of the democracy. The impact of the resulting dummy variable democracy (equal to one for those claiming to be (fully) satisfied with the democracy as practiced in Germany; 0 otherwise) is theoretically ambiguous. It may be reasonable to assume that the effectiveness of the democratic system fosters the voters' trust in the usage of taxpayers' money. The belief in an effective use of public money might increase the willingness to pay higher taxes for all voters and thus facilitates the acceptance of taxes in general. Nevertheless, a comprehensive empirical analysis of attitudes toward taxation should also control for the belief on procedural fairness of the decision making process since tax rates are determined politically.

\section{Fairness preferences}

The design of a tax system is a major part of redistributive policies in developed countries (Jesuit and Mahler, 2004). Consequently, fairness preferences are likely to shape the attitudes toward progressive taxation. Distributive preferences can be viewed as a kind of benchmark individuals compare the existing distribution with. Thus, persons favouring a distribution that guarantees everyone the (financial) means necessary for a reasonable living (need principle) should diverge in their attitudes toward redistribution from those that prefer e.g., the equity principle. The respondents' fairness preferences are indicated by their agreement to the statement that people should have a decent income even without achievement. For the dummy variable need a positive sign is expected: Other things equal, individuals

preferring a distribution according to the need principle should be more supportive of a progressive taxation than those without that kind of preference. 


\section{Fairness assessment of the status quo distribution}

Since taxes serve as an instrument for income redistribution, the assessed fairness of the income distribution is likely to have an impact on the attitudes toward tax progression. It seems reasonable to expect that individuals who perceive the existing distribution of incomes and wealth within their country as inadequate should be in favour of redistributive policies. The judgement of the existing inequality as unfair should increase the demand for redistribution (e.g., via progressive taxation). Thus, we expect that individuals assessing the existing social differences as (completely) just as well as those that do not observe a worsening of the situation of ordinary people are less likely to exhibit preferences for progressive taxes. Next to information on the respondents' assessment of the social justice, ALLBUS includes also a question related to the perceived justice of the own income situation and, thus, allows to introduce a more egocentric view on the fairness of the income distribution. The participants were asked whether the income they receive is appropriate given their achievements. Based on this information we construct the dummy variable adequate wage that equals one for respondents stating to be (at least) adequately paid relative to their effort. It is hypothesized that the individuals' satisfaction with their own earnings is related to a lower demand for redistribution and therefore progressive taxation.

\section{Individual characteristics}

A number of personal characteristics are likely to go along with preferences for progressive taxation. Some of these characteristics capture specific aspects of the above discussed aspects of self-interest, information, beliefs or fairness assessments that cannot be observed directly. In addition, however, personal characteristics account for new aspects.

Focusing on policy preferences of German citizens, it is necessary to account for the historical feature of the existence of the two former German regimes. The socialization under the communist regime of the former GDR has been found to left its marks in peoples' minds. Ockenfels and Weimann (1999) detect significant behavioural differences of Western and Eastern Germans in public good and solidarity experiments. Even ten years after the political and economic re-unification, Eastern Germans are still less content with the fairness of existing social differences in Germany than their western fellow citizens (Bischoff et al., 2008). Heinemann et al. (2009) show that individuals from the former GDR are more sceptical towards market-oriented reforms of the labour market than those socialized in the Western part of Germany. Furthermore, Alesina and Fuchs-Schündeln (2007) found that, compared to their Western German countrymen, Eastern Germans have a stronger preference for redistribution that cannot fully be explained by their relatively low income. Motivated 
by the previous findings we expect that socialization under Communism ${ }^{13}$ implies a stronger preference for progressive taxation.

There are several reasons why older people might differ in their welfare preferences from younger. First, older individuals may remember the substantial social inequalities before the expansion of the welfare state since the 1970s (Lindbeck, 1995; Heinemann, 2008). These memories may make them see today's situation less critical and therefore perceive less necessity to redistribute. Related evidence is provided by Alesina and Giuliano (2009) who find a significant impact of socialization during early adulthood. The experience of high macroeconomic volantility leads to higher preferences for redistribution. Second, uncertainty about the own economic and social status in life is larger for the young than for the old. Compared to the old, the perspective of young people with respect to their country's social situation is rather characterized by a thicker "veil of ignorance" (e.g., Rawls, 1971). As a consequence, the lower insecurity of the old may let them pay less attention to redistribution as an insurance for income risk. However, Sheffrin (1994) points to a possible status quo bias in the individual attitudes toward progressive taxation. Comparing British and US survey data, he finds a relative higher preference for progressive taxation among the population in the UK and traces this back to the fact that the British taxes were more progressive than those in the US when the surveys have been conducted. It seems reasonable to expect that the views of older individuals may be more biased in favour of the status quo than younger ones (e.g., Becker and Zweifel (2008) on health insurance). Therefore the progressivity of the German income tax system might be reflected in a higher preference for increasing marginal tax rates especially among older people. Thus, the impact of a person's age on the tax rate preferences is a priori not clear. ${ }^{14}$

A complete research design has to take account of gender since the literature reports that women have a stronger preference for income redistribution, be it through government policy or charity (e.g., Piper and Schnepf, 2008; Alesina and Giuliano, 2009; Corneo and Gruener, 2002; Delaney and O'Toole, 2008). In addition, a gender gap is reported for beliefs (e.g., Schlesinger and Heldman, 2001; Fong, 2001), risk-aversion (e.g., Meier-Pesti and Penz, 2008) and the sensitivity to inequality (e.g., Schlesinger and Heldman, 2001): Compared to males, females are more risk-averse and more sensitive to inequality. Therefore, they should be more supportive for a highly redistributive taxation.

Public employees are less likely to receive a high income than individuals employed in private enterprises. Furthermore, German officials need not to pay social security contributions.

\footnotetext{
${ }^{13}$ Since we are interested in the effect of being socialized in the GDR and not in the respondents' current state of residence, our east-dummy is equal to one for respondents' born in the former GDR.

${ }^{14}$ The existing empirical evidence is rather mixed: Both focusing on US data, McGowan (2000) observes a stronger preference for a flat tax among younger respondents than among older ones, while Hite and Roberts (1991) find a higher older people to be more likely to be in favour of steep progression.
} 
Thus, people employed in the public sector are likely to pay less of their income in taxes and mandatory contributions. When it comes to pecuniary self-interest, we expect them to be in favour of a progressive tax system (relative to private economy employees). A further argument for diverging tax preferences between workers employed in the public and private sector is related to bureaucracy theories (e.g., Tullock, 1965). In general, we would expect bureaucrats to have a distinct interest in taxes in general since they increase their budget and, thus, power. However, it is a priori not clear which kind of tax structure public sector employees prefer. Given the German income tax legislation, the progressive tax structure is accompanied by several tax exemptions making a high number of public staff necessary. This should be favoured by public employees (Niskanen, 1971). We expect therefore individuals employed in the public sector to be more likely to prefer a progressive tax scheme.

Table A1 contains the descriptive statistics of the variables included in our econometric analysis. Furthermore, we report the correlation between the exogenous variables in Table A2. It is worthwhile mentioning that the correlation between the explanatory variables is quite low indicating that the multicollinearity problem should be not very severe.

\section{Results}

Table 1 displays the results of the empirical analyses of the determinants of German voters' attitudes toward progressive taxation. We employ a probit approach since the dependent variable assumes the value of one for respondents choosing a (steeply) progressive taxation and a value of zero for those preferring proportional or regressive tax rates. The specification in the first column focuses on the individuals' self-interest. The second column includes proxies for the respondents' fairness preferences and beliefs. The variables capturing the respondents' fairness assessment are introduced in the specification shown in column 3 . The final specification includes all categories of impact factors (column 4). The individual characteristics as well as the proxies for the respondents' level of information are controlled for in all specifications. There are basically two reasons for a gradual inclusion of the different categories of impact factors: First, this proceeding serves as a robustness check. Second, some of the impact factors are likely to be channels through which other included determinants affect the individual attitudes toward progressive taxation. In their empirical analysis of German survey data, Bischoff et al. (2008) show that the respondent's fairness perception of the status quo is shaped by fairness preferences, beliefs on the sources of economic success and the degree of procedural fairness as well as self-interest and several socioeconomic factors. Thus, it is meaningful to analyze the impact of the different categories of explanatory factor both separately and jointly to get valuable information on the net effects. 
Table 1: Determinants of German voters' attitudes toward progressive taxation

\begin{tabular}{|c|c|c|c|c|}
\hline Variables & (1) & $(2)$ & (3) & $\overline{(4)}$ \\
\hline \multicolumn{5}{|c|}{ Self-interest } \\
\hline Social Status & $\begin{array}{c}-0.0234 \\
(-2.78) * * *\end{array}$ & $\begin{array}{l}-0.0204 \\
(-2.34)^{* *}\end{array}$ & $\begin{array}{c}-0.0144 \\
(-1.48)\end{array}$ & $\begin{array}{c}-0.0146 \\
(-1.48)\end{array}$ \\
\hline Social Mobility & $\begin{array}{c}-0.0109 \\
(-1.42)\end{array}$ & $\begin{array}{c}-0.0074 \\
(-0.95)\end{array}$ & $\begin{array}{c}-0.0078 \\
(-0.92)\end{array}$ & $\begin{array}{c}-0.0033 \\
(-0.38)\end{array}$ \\
\hline \multicolumn{5}{|c|}{ Information } \\
\hline University & $\begin{array}{l}0.0315 \\
(1.07)\end{array}$ & $\begin{array}{c}0.0078 \\
(0.25)\end{array}$ & $\begin{array}{l}0.0304 \\
(0.95)\end{array}$ & $\begin{array}{l}0.0131 \\
(0.39)\end{array}$ \\
\hline Importance Politics & $\begin{array}{c}-0.0311 \\
(-1.35)\end{array}$ & $\begin{array}{c}-0.0364 \\
(-1.52)\end{array}$ & $\begin{array}{l}-0.0396 \\
(-1.44)\end{array}$ & $\begin{array}{l}-0.0450 \\
(-1.73)^{*}\end{array}$ \\
\hline \multicolumn{5}{|c|}{ Fairness preference } \\
\hline Need & & $\begin{array}{c}0.0587 \\
(2.59)^{* * *}\end{array}$ & & $\begin{array}{c}0.0563 \\
(2.26)^{* *}\end{array}$ \\
\hline \multicolumn{5}{|c|}{ Beliefs } \\
\hline Effort & & $\begin{array}{c}-0.0974 \\
(-4.36)^{* * *}\end{array}$ & & $\begin{array}{l}-0.0654 \\
(-2.45)^{* *}\end{array}$ \\
\hline Democracy & & $\begin{array}{c}0.0323 \\
(1.40)\end{array}$ & & $\begin{array}{c}0.0515 \\
(2.00)^{* *}\end{array}$ \\
\hline \multicolumn{5}{|c|}{ Fairness assessment } \\
\hline Social Differences & & & $\begin{array}{c}-0.0736 \\
(-2.71)^{* * *}\end{array}$ & $\begin{array}{l}-0.0497 \\
(-1.70)^{*}\end{array}$ \\
\hline Ordinary People & & & $\begin{array}{c}-0.0867 \\
(-2.82)^{* * *}\end{array}$ & $\begin{array}{c}-0.1051 \\
(-3.31)^{* * *}\end{array}$ \\
\hline Adequate Wages & & & $\begin{array}{c}-0.0872 \\
(-3.39)^{* * *}\end{array}$ & $\begin{array}{c}-0.0877 \\
(-3.31)^{* * *}\end{array}$ \\
\hline \multicolumn{5}{|c|}{ Others } \\
\hline Age & $\begin{array}{l}0.0010 \\
(1.55)\end{array}$ & $\begin{array}{c}0.0016 \\
(2.23)^{* *}\end{array}$ & $\begin{array}{c}0.0020 \\
(2.60)^{* * *}\end{array}$ & $\begin{array}{c}0.0026 \\
(3.22)^{* * *}\end{array}$ \\
\hline Female & $\begin{array}{c}0.0289 \\
(1.32)\end{array}$ & $\begin{array}{c}0.0362 \\
(1.61)\end{array}$ & $\begin{array}{c}0.0245 \\
(1.00)\end{array}$ & $\begin{array}{c}0.0333 \\
(1.35)\end{array}$ \\
\hline East & $\begin{array}{c}0.0053 \\
(0.23)\end{array}$ & $\begin{array}{l}0.0045 \\
(0.19)\end{array}$ & $\begin{array}{c}-0.0173 \\
(-0.68)\end{array}$ & $\begin{array}{c}-0.0062 \\
(-0.24)\end{array}$ \\
\hline Public Sector & $\begin{array}{l}0.0515 \\
(1.75)^{*}\end{array}$ & $\begin{array}{l}0.0525 \\
(1.79)^{*}\end{array}$ & $\begin{array}{l}0.0540 \\
(1.70)^{*}\end{array}$ & $\begin{array}{l}0.0587 \\
(1.90)^{*}\end{array}$ \\
\hline \multicolumn{5}{|c|}{ Regression diagnostic } \\
\hline $\begin{array}{l}\mathrm{p} \text {-value } \\
\text { (joint significance) }\end{array}$ & 0.0005 & 0.0000 & 0.0000 & 0.0000 \\
\hline Observations & 1324 & 1223 & 1071 & 1015 \\
\hline Pseudo- $R^{2}$ & 0.0212 & 0.0443 & 0.0604 & 0.0859 \\
\hline
\end{tabular}

Marginal effect are reported. z-values are given in parentheses. */**/*** denotes significance at $10 \% /$ $5 \% / 1 \%$ level. 
The findings suggests that self-interest determines the individual preferences for progressive taxation only partially. ${ }^{15}$ While the experience of social mobility fails to be significant in all four regressions, the current social status affects the individual attitudes toward tax progression as long as the respondent's fairness assessment of the status quo distribution is not included. As anticipated, individuals at the top of the society tend to be less likely to favour progressive tax rates. ${ }^{16}$

Indicating that the attitudes toward different tax structures are not shaped solely by selfinterest, an essential overall result is the relevance of fairness aspects. First, the fairness preferences are found to be a significant determinant of individual tax preferences: The probability of supporting progressive taxation is nearly 6 percentage points higher for individuals preferring a distribution according to the need principle than for those entertaining different fairness preferences. Second, the respondents' economic beliefs are reflected in their views on tax policy. Persons attributing differences in social status to the interpersonal variation in effort show a 6.5 to 9.7 percentage points lower likeliness of favouring marginal tax rates that increase in income. The impact of the belief concerning the functioning of the democratic system is, however, less clear cut: Controlling for the perceived fairness of the status quo, we find that the satisfaction with the effectiveness of the political system leads to a 5 percentage points higher probability of demanding a relatively higher taxation of wealthy persons.

Little surprising, the assessed justice of the existing distributive situation is a relevant driving factor for the individual tax preference. Being content with the fairness of social differences lowers the probability of favouring tax progressivity by 5 to 7 percentage points. Quantitatively more important is the perceived situation of ordinary people. Individuals who do not gauge a worsening of the situation of ordinary people show a 8.7 to 10.5 lower tendency to demand a disproportional higher taxation of high income recipients. Finally, the satisfaction with the fairness of the own earnings leads to a significantly lower support for progressive taxes. The perceived justice of the own earnings has (with a marginal effect of about 9 percentage points) proven to be relevant for the formation of welfare state preferences.

While our proxies for the respondents' level of information do not contribute significantly to the explanation of tax attitudes, the respondents' age and employment in the public sector are found to have a significant impact on the tax preferences. Both public employees and older people are more likely to be in favour of a progressive taxation. Surprisingly, the results do not confirm a specific "GDR-effect" on people's preferences for progressive

\footnotetext{
${ }^{15}$ Several other empirical studies on tax and redistributive preferences also provide a mixed evidence on the relevance of self-interest (Sears and Funk, 1991).

${ }^{16}$ The variable's social status loss of significance is mainly a result of its positive correlation with the variable adequate wage. The latter is a rather self-centered view on the justice of incomes and may reflect partly the respondents' self-interest.
} 
taxation. Since different attitudes toward the welfare state between Eastern and Western Germans have been confirmed empirically (e.g., by Alesina and Fuchs-Schündeln, 2007) the missing significance of the east-dummy may indicate that we already controlled for the factors that draw responsible for the observable divergence in redistributive preferences.

\section{Conclusion}

Economic approaches to explain the size of the welfare state are usually based on the assumption of purely rational individuals. Thus, individual demand for redistribution should result from the position in the income distribution. Our findings indicate that an analysis of individual tax preferences that focuses solely on purely selfish impact factors leaves out an important part of the story. Individuals do not only choose the tax system that is most beneficial to them but care also about its fairness. Consequently, even high income individuals may support a tax system where they have to pay a larger share of their income in taxes than low income earners. Especially the fairness preferences, beliefs on the reasons for inequality and the perceive justice of the status quo distribution contribute to the explanation of individual heterogeneity in attitudes toward progressive taxation.

Our findings are highly relevant when it comes to actual implementation of tax reforms. To get the necessary voter support for potentially growth-enhancing tax policies (via a lower degree of tax progression) it is important to address also the fairness-related concerns about such a reform. Focusing on fairness aspects seems to be an essential issue for a successful selling of reforms. Especially the perception of decreasing social justice determines the voters' preference for a progressive taxation. Since high marginal tax rates may lower individual work incentives, they may result in a higher injustice of the income distribution. To overcome this potential vicious circle, politicians should e.g., stress the relevance of industriousness for economic success as well as the impact of incentives for individual effort. Given our results, the belief that everyone is responsible for his own economic situation should increase also the voters' support for tax reforms aiming to reduce disincentives resulting from marginal tax rates increasing in income. 


\section{References}

Ackert, L.F., Martinez-Vazquez, J., and Rider, M. (2006). Tax Policy Design in the Presence of Social Preferences: Some Experimental Evidence. Andrew Young School of Policy Studies Research Paper Series.

Alesina, A., E. Glaeser, and B. Sacerdote (2001). Why Doesn't the United States Have a European-Style Welfare State? Brookings Papers on Economic Activity 2, 187254 .

Alesina, A. and G.M. Angeletos (2005). Fairness and Redistribution. American Economic Review 95, 961-980.

Alesina, A. and N. Fuchs-Schündeln (2007). Good-Bye Lenin (or Not?): The Effect of Communism on People's Preferences. American Economic Review 97, 1507-1528.

Alesina, A., P. Giuliano (2009). Preferences for Redistribution. NBER Working Paper 14825.

Becker K. and P. Zweifel (2008). Age and Choice in Health Insurance. Evidence from a Discrete Choice Experiment. The Patient: Patient-Centered Outcomes Research. 1, $27-40$.

BÉnAbou, R. and E.A. OK (2001). Social Mobility and the Demand for Redistribution: The POUM Hypothesis. Quaterly Journal of Economics 116, 447-487.

Bischoff, I., F. Heinemann, and T. Hennighausen (2008). Individual Determinants of Social Fairness Perception - The Case of Germany. ZEW Working Paper 08-063.

Boeri, T., A.H. Börsch-Supan, and G. Tabellini (2002). Pension Reforms and the Opinions of European Citizens. American Economic Review 92, 396-401.

Boeri, T. and G. TABellini (2007). Does Information Increase Political Support for Pension Reform? Bocconi University and IGIER, mimeo.

Corneo, G. and H.P. Grüner (2002). Individual Preferences for Political Redistribution. Journal of Public Economics 83, 83-107.

Delaney, L. and F.O. O'Toole (2008). Individual, Household and Gender Preferences for Social Transfers. Journal of Economic Psychology 29, 348-359.

Dornstein, M. (1987). Taxes: Attitudes and Perceptions and Their Social Bases. Journal of Economic Psychology 2, 268-298. 
Edlund, J. (1999). Attitudes Towards Tax Reform and Progressive Taxation: Sweden 1991-96. Acta Sociologica 42, 337-355.

EdLund, J. (2003). Attitudes Towards Taxation: Ignorant and Incoherent? Scandinavian Political Studies 26, 145-167.

Faravelli, M. (2007). How Context Matters: A Survey Based Experiment on Distributive Justice. Journal of Public Economics 91, 1399-1422.

Fenr, E. and K.M. Schmidt (1999). A Theory of Fairness, Competition, and Cooperation. Quarterly Journal of Economics 114, 817-868.

Fong, C. (2001). Social Preferences, Self-Interest, and the Demand for Redistribution. Journal of Public Economics 82, 225-246.

Heinemann, F. (2008). Is the Welfare State Self-Destructive? A Study of Government Benefit Morale. Kyklos 61, 237-257.

Heinemann, F., I. Bischoff, and T. Hennighausen (2009). Choosing from the Reform Menu Card: Individual Determinants of Labour Market Policy Preferences. Jahrbücher für Nationalökonomie und Statistik 229, 180-197.

Hettich, W. and S.L. Winer (1997). The Political Economy of Taxation. In: D.C. Mueller. Perspectives on Public Choice. Cambridge, 481-505.

Hite, P.A. and M.L. Roberts (1991). An Experimental Investigation of Taxpayer Judgments in Rate Structure in the Individual Income Tax System. Journal of American Taxation Association 13, 47-63.

Jesuit, D. and V. Mahler (2004). State Redistribution in a Comparative Perspective. A Cross-National Analysis of the Developed Countries. Luxembourg Income Study Working Paper 392.

Konow, J. (2003). Which Is the Fairest One of All? A Positive Analysis of Justice Theories. Journal of Economic Literature 41, 1188-1239.

Leventhal, G. (1980). What Should Be Done With Equity Theory? New Approaches to the Study of Fairness in Social Relationships. In: Gergen, K.J., M.S. GreenberG, and R.H. Willis (ed.). Social Exchange, Advances in Theory and Research. New York, 237-257.

LindBeck, A. (1995). Welfare State Disincentives with Endogenous Habits and Norms. Scandinavian Journal of Economics 97, 447-494. 
McGowan, J.R. (2000). The Effect of Political Affiliation on Taxpayers Attitudes Toward Alternative Tax System. Journal of the American Taxation Association 22, 111-128.

Meier-Pesti, K. and E. Penz (2008). Sex or Gender? Expanding the Sex-Based View by Introducing Masculinity and Feminity as Predictors of Financial Risk Taking. Journal of Economic Psychology 29, 180-196.

Meltzer, A.H. and S.F. Richard (1981). A Rational Theory of Size of Government. Journal of Political Economy 89, 914-927.

Niskanen, W.A.(1971). Bureaucracy and representative government. Chicago.

Ockenfels, A. and J. Weimann (1999). Types and Patterns: An Experimental EastWest-German Comparison and Solidarity. Journal of Public Economics 71, 275-287.

Piketty, T. (1995). Social Mobility and Redistributive Politics. Quarterly Journal of Economics 3, 551-583.

Piper, G. and S.V. Schnepf (2008). Gender Differences in Charitable Giving in Great Britain. Voluntas 19, 103-124.

Ravallion, M. and M. Lokshin (2000). Who Wants to Redistribute? The Tunnel Effect in 1990s Russia. Journal of Public Economics 76, 87-104.

Rawls, J. (1971). A Theory of Justice. Cambridge.

Roberts, M.L., P.A. Hite, and C.F. Bradley (1994). Understanding Attitudes Toward Progressive Taxation. Public Opinion Quarterly 58, 165-190.

Schlesinger, M. and C. Heldman (2001). Gender Gap or Gender Gaps? New Perspective on Support for Government Action and Policies. Journal of Politics 63, 59-92.

Sears, D.O. and C.L. Funk (1991). The Role of Self-Interest in Social and Political Attitudes. In: M.P. ZannA. Advances in Experimental Social Psychology Vol. 24. New York, 1-91.

Sheffrin, S.M. (1993). What Does the Public Believe about Tax Fairness? National Tax Journal 46, 301-308.

Sheffrin, S.M. (1994). Perception of Fairness in the Crucible of Tax Policy. In: Slemrod, J. (ed.) Tax Progressivity and Income Inequality. Cambridge, 309-334.

Slemrod, J. (2006). The Role of Misconceptions in Support for Regressive Tax Reform. National Tax Journal 59, 57-75. 
Sondak, H. and T.R. Tyler (2007). How Does Procedural Justice Shape the Desirability of Markets? Journal of Economic Psychology 28, 79-92.

TulLock, G. (1965). The Politics of Bureaucracy. Washington D.C..

Tyler, T.R. (2000). Social Justice, Outcome and Procedure. International Journal of Psychology 35, 117-125.

Wilensky, H.L. (1976). The 'New Corporatism'. Centralization and The Welfare State. London. 


\section{Appendix}

Table A1: Descriptive Statistics

\begin{tabular}{lccccc}
\hline \hline Variables & Observations Mean Std. Dev. Min. Max. \\
\hline \multicolumn{7}{c}{ Dependent Variable } \\
\hline Tax Progression & 1364 & 0.7957 & 0.4034 & 0 & 1 \\
\hline \multicolumn{7}{c}{ Self-interest } \\
\hline Social Status & 1408 & 5.4622 & 1.4883 & 1 & 10 \\
Social Mobility & 1401 & 0.2191 & 1.5762 & -9 & 6 \\
\hline \multicolumn{7}{c}{ Information } \\
\hline University & 3757 & 0.1392 & 0.3462 & 0 & 1 \\
Importance Politics & 3804 & 0.6728 & 0.4693 & 0 & 1 \\
\hline \multicolumn{7}{c}{ Fairness } & preference \\
\hline Need & 3665 & 0.4836 & 0.4998 & 0 & 1 \\
\hline \multicolumn{7}{c}{ Beliefs } \\
\hline Effort & 3595 & 0.5706 & 0.4951 & 0 & 1 \\
Democracy & 3713 & 0.4929 & 0.5000 & 0 & 1 \\
\hline \multicolumn{7}{c}{ Others } \\
Social Differences & Fairness assessment \\
Ordinary People & 3676 & 0.4178 & 0.4933 & 0 & 1 \\
Adequate Wages & 3563 & 0.7340 & 0.4419 & 0 & 1 \\
\hline \multicolumn{7}{c}{47.58} & 17.23 & 18 & 95 \\
\hline Age & 1210 & 0.5240 & 0.4996 & 0 & 1 \\
Female & 3804 & 0.5209 & 0.4996 & 0 & 1 \\
East & 3804 & 0.3826 & 0.4861 & 0 & 1 \\
Public Sector & 3804 & 0.1255 & 0.3314 & 0 & 1 \\
\hline \hline
\end{tabular}


Table A2: Correlations between the explanatory variables

\begin{tabular}{|c|c|c|c|c|c|c|c|c|c|c|c|c|c|c|c|}
\hline & $\begin{array}{c}\text { Net } \\
\text { Income }\end{array}$ & $\begin{array}{l}\text { Social } \\
\text { Status }\end{array}$ & $\begin{array}{c}\text { Social } \\
\text { Mobility }\end{array}$ & University & $\begin{array}{c}\text { Importance } \\
\text { Politics }\end{array}$ & Need & Effort & Democracy & $\begin{array}{c}\text { Social } \\
\text { Differences }\end{array}$ & $\begin{array}{c}\text { Ordinary } \\
\text { People }\end{array}$ & $\begin{array}{c}\text { Adequate } \\
\text { Wages }\end{array}$ & Age & Female & East & $\begin{array}{l}\text { Public } \\
\text { Sector }\end{array}$ \\
\hline Net Income & 1 & & & & & & & & & & & & & & \\
\hline Social Status & $.30^{* * *}$ & 1 & & & & & & & & & & & & & \\
\hline Social Mobility & $.22^{* * *}$ & $.41^{* * *}$ & 1 & & & & & & & & & & & & \\
\hline University & $.34^{* * *}$ & $.21^{* * *}$ & $.06^{* *}$ & 1 & & & & & & & & & & & \\
\hline Importance Politics & $.19^{* * *}$ & $.16^{* * *}$ & $.05^{*}$ & $.12^{* * *}$ & 1 & & & & & & & & & & \\
\hline Need & $-.17^{* * *}$ & $-.07 * * *$ & $-.07 * * *$ & $-.10^{* * *}$ & $-.11^{* * *}$ & 1 & & & & & & & & & \\
\hline Effort & .03 & $.06^{* *}$ & $.07^{* *}$ & $-.09 * * *$ & $.03^{* *}$ & $-.06^{* * *}$ & 1 & & & & & & & & \\
\hline Democracy & $.15^{* * *}$ & $.15^{* * *}$ & $.11^{* * *}$ & $.08 * * *$ & $.14^{* * *}$ & $-.08 * * *$ & $.11^{* * *}$ & 1 & & & & & & & \\
\hline Social Differences & $.14^{* * *}$ & $.10^{* * *}$ & $.11^{* * *}$ & .02 & $.06^{* * *}$ & $-.09 * * *$ & $.36^{* * *}$ & $.24^{* * *}$ & 1 & & & & & & \\
\hline Ordinary People & $.13^{* * *}$ & $.11^{* * *}$ & $.06^{* *}$ & $.08^{* * *}$ & $.07^{* * *}$ & $-.10^{* * *}$ & $.10^{* * *}$ & $.15^{* * *}$ & $.21^{* * *}$ & 1 & & & & & \\
\hline Adequate Wage & $.16^{* * *}$ & $.20 * * *$ & $.15^{* * *}$ & .03 & $.08^{* * *}$ & $-.06 * *$ & $.15^{* * *}$ & $.18^{* * *}$ & $.22^{* * *}$ & $-.13^{* * *}$ & 1 & & & & \\
\hline Age & $.07^{* * *}$ & -.03 & $-.15^{* * *}$ & -.02 & -.02 & $.04^{* *}$ & $.14^{* * *}$ & $.05^{* * *}$ & $.06^{* * *}$ & .02 & $.13^{* * *}$ & 1 & & & \\
\hline Female & $-.36 * * *$ & -.03 & -.03 & $-.09 * * *$ & $-.08^{* * *}$ & $.05^{* * *}$ & $-.03^{*}$ & $-.05^{* * *}$ & $-.04^{* * *}$ & $.06^{* * *}$ & $-.06^{* *}$ & $.07^{* * *}$ & 1 & & \\
\hline East & $-.22 * * *$ & $-.26 * * *$ & $-.13^{* * *}$ & -.02 & $-.10 * * *$ & $.10^{* * *}$ & $-.07 * * *$ & $-.18^{* * *}$ & $-.17^{* * *}$ & $.10^{* * *}$ & $-.15^{* * *}$ & $.06^{* * *}$ & .02 & 1 & \\
\hline Public Sector & $.25^{* * *}$ & $.11^{* * *}$ & $.05^{* *}$ & $.19^{* * *}$ & $.07^{* * *}$ & $-.06^{* * *}$ & $-.07 * * *$ & $.03^{*}$ & -.01 & -.01 & -.01 & $-.13^{* * *}$ & $.05^{* * *}$ & $-.07 * * *$ & 1 \\
\hline
\end{tabular}

$* / * * / * * *$ denotes significance at $10 \% / 5 \% / 1 \%$ level. 
Table A3: Variable Explanations

\begin{tabular}{|c|c|c|c|c|}
\hline Variable & Unit & Explanation & Categories & $\begin{array}{l}\text { Corresponding } \\
\text { ALLBUS question }\end{array}$ \\
\hline \multicolumn{5}{|c|}{ Dependent variable } \\
\hline Tax Progression & Dummy & $\begin{array}{l}\text { Respondent's preference for progressive } \\
\text { tax rates. }\end{array}$ & $\begin{array}{l}1 \text {, if the respondent } \\
\text { favours a (steep) progression. }\end{array}$ & v714 \\
\hline \multicolumn{5}{|c|}{ Self-interest } \\
\hline Social Status & $\begin{array}{l}\text { Ordinal } \\
\text { scale }\end{array}$ & $\begin{array}{l}\text { Respondent's position in } \\
\text { the social stratum. }\end{array}$ & 1 (bottom) $-10($ top $)$ & v724 \\
\hline Social Mobility & $\begin{array}{l}\text { Ordinal } \\
\text { scale }\end{array}$ & $\begin{array}{l}\text { Change in respondent's position in the } \\
\text { social stratum during the last ten years. }\end{array}$ & $-9-6$ & v724/ v725 \\
\hline \multicolumn{5}{|c|}{ Information } \\
\hline University & Dummy & Respondent's level of education. & $\begin{array}{l}1 \text {, if the respondent has an } \\
\text { university (for applied science) degree. }\end{array}$ & $\mathrm{v} 230 / \mathrm{v} 231$ \\
\hline $\begin{array}{l}\text { Importance } \\
\text { Politics }\end{array}$ & Dummy & $\begin{array}{l}\text { Politics strongly influence } \\
\text { our lives. }\end{array}$ & 1 , if the respondent approves. & v210 \\
\hline \multicolumn{5}{|c|}{ Fairness preference } \\
\hline Need & Dummy & $\begin{array}{l}\text { Decent income even } \\
\text { without achievement. }\end{array}$ & 1 , if the respondent approves. & v167 \\
\hline \multicolumn{5}{|c|}{ Beliefs } \\
\hline Effort & Dummy & $\begin{array}{l}\text { Differences in social standing as } \\
\text { incentive for individual achievement. }\end{array}$ & 1, if the respondent approves. & v169 \\
\hline Democracy & Dummy & $\begin{array}{l}\text { Satisfaction with the } \\
\text { German democracy. }\end{array}$ & 1 , if the respondent is (fully) satisfied. & v211 \\
\hline \multicolumn{5}{|c|}{ Fairness assessment } \\
\hline $\begin{array}{l}\text { Social } \\
\text { Differences }\end{array}$ & Dummy & The social differences are just. & 1 , if the respondent approves. & v170 \\
\hline Ordinary People & Dummy & $\begin{array}{l}\text { Life for ordinary people is } \\
\text { not getting worser. }\end{array}$ & 1 , if the respondent approves. & v27 \\
\hline Adequate Wage & Dummy & Just pay given skills and effort. & 1 , if the respondent approves. & v734 \\
\hline \multicolumn{5}{|c|}{ Others } \\
\hline Age & $\begin{array}{l}\text { Discrete } \\
\text { variable }\end{array}$ & Age of the respondent. & $18-95$ & v219 \\
\hline Female & Dummy & Sex of the respondent. & 1 , if the respondent is female. & v216 \\
\hline East & Dummy & Origin of the respondent. & 1 , if the respondent has been born in the former GDR. & v465 \\
\hline $\begin{array}{l}\text { Public } \\
\text { Sector }\end{array}$ & Dummy & $\begin{array}{l}\text { Employment of the respondent } \\
\text { in the public sector. }\end{array}$ & 1 , if the respondent is a public employee. & $\mathrm{v} 256$ \\
\hline
\end{tabular}

